\title{
THE EUROPEAN UNION BATTLE GROUPS IN THE DEVELOPMENT OF THE COMMON SECURITY AND DEFENSE POLICY
}

Keywords: Common security and defense policy, European Union, battle groups, multinational military units, Visegrad Group, Weimar Triangle

\begin{abstract}
The Common Security and Defense Policy (CSDP) enables European Union to take a leading role in peace - keeping operations, conflict prevention and the strengthening of the international security. It is an integral part of EU's comprehensive approach towards crisis management, drawing on civilian and military assets. EU Battle Groups remain important for CSDP as the only military capabilities on standby for possible EU operations and as they are helping to reinforce the effectiveness Member States' of military forces. EU Battle Groups are multinational, military units and form an integral part of the EU's military rapid reaction capacity to respond to emerging crises and conflicts around the world. Therefore, Polish diplomacy actively acts in various forums (the Visegrad Group, the Weimar Triangle) to bolster the CSDP. Poland actively involved in the implementation of the CSDP through participation in EU Battle Groups.
\end{abstract}

\section{INTRODUCTION}

European integration has always been related to security. The "founding fathers" chose coal and steel as the basis for their unique experiment in the field of integration. However, the main motive for integration was

1 Dariusz Górniak, General of the Polish Army, former commander of $12 \mathrm{BZ}$ to them. Gen. Józef Haller in Szczecin, PhD student at IPiE, dargor2003@interia.pl. 
to provide peace and security, above all for Europe and later for the world. The main role in shaping transatlantic security was fulfilled by the North Atlantic Alliance established in 1949 (Giddis, 2008). Under the cover of the US "nuclear umbrella", however, the activities of the EEC and sectoral organizations in Europe the European Coal and Steel Community and the European Atomic Energy Community (Euratom) have grown and consolidated. Subsequent processes of Western European integration have facilitated the economic development of the member states, improved the living conditions of people and allowed free movement of persons, goods, capital and services among the members of European communities. They also made it possible to democratize European relations and make beneficial arrangements with many countries of the world, which made it possible to better sell goods from EEC countries and facilitate the acquisition of raw materials. They created the economic and social foundations for the safe development of the continent.

NATO's strategy was dominated by Americans with the greatest economic, military and political capabilities. Proposals to create a more independent European security system of Western European countries were usually opposed by Washington politicians.

In Western Europe, however, specific sovereignty was not abandoned. Continental European thinking from the early 1950s was based on the concept of Europe as the third force alongside the United States and the Soviet Union. After the failed project of the Dunkirk Alliance, the socalled Western European Union (WEU) was created in 1947 by the Treaty of Brussels (France, the United Kingdom and three Benelux countries), becoming the outpost of the North Atlantic Treaty. In order to oppose the German remilitarization project, Paris came up with a concept that assumed the creation of a joint army of Western European countries. In 1950, the French Defense Minister René Pleven announced plans for the European army that allowed the participation of the Federal Republic of Germany in the defense of Western Europe. It involved the initiative of the European Defense Community (EDC). This initiative gained the support of the United States, but without the unequivocal position of Great Britain. As a result, the plan was rejected by the French National Assembly. 
With the failure of plans to create a European Defense Community in 1954, defense was outside the integration program. The Europeans also rejected the French Fouchet plan in 1961 aimed at close political cooperation between the six states and the common security and defense policy (Ciupiński, 2001, pp 130-135). Over the following years, the matter has not progressed. From time to time, it was referred to, but not directly (e.g. to the need to create a European pillar of NATO established by the US government under the presidency of John Kennedy).

The collapse of communism in 1989 transformed the geopolitical scene in Europe and renewed the debate on defense. At the beginning of the 1980 s, the demands of a fuller independence from the US began in Western Europe, not only by tightening integration within the EC, but also by developing a European identity of security and defense on the institutional basis of the Western European Union. Basing the foundations of European security on the WEU seemed to be beneficial for the Western European countries, the more so as the legal Treaty of Brussels, contrary to the Washington Treaty, assumed automatic military assistance in the event of an attack on one of the parties. The first step to give it new impulses was the signing of the Rome Declaration. The Declaration of 27 October 1984 was signed by: Belgium, France, the Netherlands, Luxembourg, Germany, Great Britain and Italy. With time, two trends appeared in Western Europe: the first was the so-called "European trend", backed by France, which being outside NATO since 1966 has sought to transform WEU into an institution capable of providing security to Western Europe without US involvement. The second trend - "Atlantic", represented mainly by the United Kingdom, strongly opposed the agreement of the national strategies of the Western European Union in the field of security without the participation of the United States and opted for the supremacy of NATO and transatlantic cooperation in shaping European security.

The issue of common defense was discussed in Maastricht, but it was included in the area of international cooperation very slowly. The signing of the Maastricht Treaty eventually accompanied the launch of the Common Foreign and Security Policy (CFSP). After the creation of the European Union, there was a slow expansion of common military structures (Hamon, Keller, 1997, p. 453). The Common Foreign and Security Policy, 
constituting the second pillar of the EU established in Maastricht, has become the continuation of the European Political Cooperation. The main CFSP objectives include: protecting common values, basic interests and EU independence; strengthening the security of the Union and its Member States in all its forms; protecting world peace and the principles and objectives of the United Nations Charter and OSCE; supporting international cooperation; supporting and strengthening democracy and the rule of law and protecting human rights and fundamental freedoms; harmonizing national points of view, including the development of agreed positions on joint diplomatic actions. In comparison with the EWP established in 1970, the Common Foreign and Security Policy was extended to the sphere of defense.

The Maastricht Treaty establishing the European Union formulates its general tasks in protecting common values, strengthening the security of the EU and the Member States, developing multilateral cooperation and consolidating democracy and the rule of law. The principles of cooperation in the field of cooperation for the common foreign and security policy were defined in Title $\mathrm{V}$ of the EU Treaty. It consisted of articles J (from J.1 to J.11). One of the articles (J.4) stated, among others that "The common foreign and security policy shall include all questions related to the security of the Union, including the eventual framing of a common defense policy, which might in time lead to a common defense" (Czapliński, Ostrihansky, Wyrozumski, 1996, p. 127). To improve the operation and cooperation with the Western European Union it was decided to move its headquarters from London to Brussels and establish a uniform representation of the European Union and WEU at the NATO Headquarters. The model of the European security system initiated in this way was based on the multitude of specialized organizations. They form a complex "architecture" of complementary structures, agreements and systems. This system uses the achievements of the UN Security Council, but the basis for its operation is mainly composed of specialized structures of NATO, OSCE and the European Union, recognized in the literature as so-called European security triangle (Cziomer, 2001, p. 72). 
The concept of the European identity of security and defense was clarified in the early nineties at the next NATO summits in Berlin and Brussels. Therefore, it was born in the NATO environment, not in the European Union environment. The NATO summit in January 1994 in Brussels supported the proposal to create a European rapid reaction force within its framework, in the form of Combined Joint Task Forces (CJTF). However, it was recognized that the European defense policy should serve to strengthen the "transatlantic partnership" (Zięba, 2000, p. 62).

Creating a new security system in Europe in the nineties was not easy. Certainly, there were factors that supported it and caused difficulties (Fijałkowska, Żukrowski, 2002, pp. 39-49). The progressive cooperation of various European organizations, and especially the gradual evolution of NATO from the military-political alliance into a wider political and defense organization evolving towards the European organization of collective security has become a supporting factor. On November 14, 1995, the WEU Council of Ministers adopted a joint document in Madrid entitled: European Security: a Common Concept of the 27 WEU Countries. The Treaty of Amsterdam of 1997 confirmed the need to further strengthen EU relations in matters of security with NATO. It was decided to make available WEU's operational capabilities for the European Union and its adoption of Petersburg tasks and indicated the possibility of WEU integration with the European Union. The Treaty of Amsterdam provided, inter alia, the inclusion of the EU competence in the field of CFSP St. Petersburg missions (humanitarian and rescue missions, restoration operations and crisis management). In a compromise manner, the Office of the High Representative for Common Foreign and Security Policy was established, combined with the position of the Secretary General of the Council of the European Union and the consent to establish a political planning unit at the General Secretariat of the Council of the EU.

The Nice Treaty stated that common foreign and security policy shall cover all matters related to the Union's security, including the gradual definition of a common defense policy that could lead to 
a common defense. The Treaty of Nice was signed on February 26, 2001. Such a defined EU policy does not weaken the specific dimension of the security and defense policy of some Member States. It respects the obligations of states stemming from the North Atlantic Treaty, which consider that their joint defense is carried out within the framework of NATO and is consistent with the common security and defense policy adopted in this framework. The gradual definition of a common defense policy was to be supported by cooperation between them in the field of armaments to the extent that states deem it appropriate. The matters in the treaty included humanitarian and rescue missions, peacekeeping missions and armed missions to manage crises, including peacemaking.

Fifteen EU members decided on the need to strengthen the defense capabilities of the Member States, in particular to build from scratch their own military structure. According to the assumptions, it would have an integral decision-making and operational system, ensuring the possibility of independent intervention in crises on the European continent. At the summit in Helsinki (December 1999) the shape of the so-called European operational objective was developed, specifying what anti-crisis forces Europe would like to have at its disposal (Helsinki European Council...). The leaders of the European Union officially proclaimed the establishment of a Common Security and Defense Policy (by introducing the CESDP abbreviation - Common European Security and Defense Policy) as a tool of the Common Foreign and Security Policy. The CESDP formula is interchanged with the definition of ESDP - European Security and Defense Policy. In November 2000, during the first review conference, each of the member countries of the Union declared what military forces it was able to allocate to joint peace operations.

At the moment, the international community must reckon with the need to take the fastest activities related to response on wide range of security threats, such as terrorism, local or regional armed conflicts. Contemporary armed conflicts have most often similar causes: economic, political, territorial, religious and ethnic. The European Union Battle Groups (EU BG) concept is a response to these challenges by enabling immediate displacement of prepared forces and conduct of crisis management operations in European Union and outside its area. 
In order to achieve a higher level of collective security, Member States more often combine their forces and means, creating systems of international security. The political dimension of these alliances is subject to many changes, depending on the relations and cooperation between the Member States. Characteristic is that political changes and peaceful transformation after the end of "cold war", as well as extension of European integration with the new Member States of "Eastern bloc" did not reject the military argument in the way of solving international conflicts and crisis management. Military potential of States remains one of the primary arguments of politics during the war and peace. Subject to changes are functions and tasks of the armed forces, used often as a means of crisis management. At the beginning of the $21^{\text {st }}$ century analyzing the course of developments in the European Union it is necessary to emphasize the fact that security and defense are included in the policy issues. According to the Treaty on European Union, one of the most important objectives of the European Union is "to confirm its identity on the international stage, especially through implementation of the Common Foreign and Security Policy (CFSP), including ultimately, term of common defense policy, which might lead to common defense".

\section{BATTLE GROUPS AS PART OF THE EUROPEAN UNION CRISIS RESPONSE POLICY}

At the end of the $20^{\text {th }}$ century, countries of the European Union have started to attach more and more importance to the construction of new defence capabilities of the European Union, independent of the North Atlantic Alliance. During the European Council meeting in Helsinki at the December 1999, it was stated that an important part of crisis management shall be the development of joint military capabilities. Helsinki European Headline Goal 2003 defined that in the context of the development of the European Security and Defence Policy Member States had to be ready to send to the area of crisis forces able to operate independently. It required that Member States be able to deploy 60,000 troops within 60 days and sustainable for a year (Zięba, 2005, pp. 47-99) starting from 
2003. These capabilities were to be used in support of Petersburg missions, for example, humanitarian and rescue tasks, peacekeeping tasks, tasks of combat forces in crisis management, including peacemaking. The idea of the creation of the European Rapid Reaction Forces proved to be too ambitious, despite the fact that the armed forces of the Member States had approximately 2 million troops. In connection with the failure to create the European Rapid Reaction Forces, the decision was made to implement the project in a different way.

The concept of creation the EU BG was outlined by Britain, France and Germany in February 2004 specifically as part of the negotiations over "Headline Goal 2010". The Battle Groups (BG) were presented as a new approach to force packaging and were designed to improve the capacity of the Union for rapid reaction. The objective was to give the Union greater operational flexibility with a specific, but not exclusive, responsibility to act in response to requests from the UN, particularly for operations in Africa. Operation Artemis, which took place in the Democratic Republic of Congo between July and September 2004 has become in some ways the template following the request from the UN Security General for an interim emergency multinational force (Lindley-French, Headline Goal 2010, p.2). Additionally it extended its scope with the Petersburg plus tasks and mission, which included:

- joint disarmament operations - JDO,

- support for countries in fight against terrorism,

- operation in support for Security Sector Reform.

The Treaty crisis response missions and these extended were formulated very generally. Only in the course of further work, there have been attempts to determine the nature of the measures envisaged and, as a result, five the most likely scenarios of military response the European Union were indicated. Battle Groups are employable across the full range of tasks listed in Article 43(1) of the Treaty on European Union and those identified in the context of the implementation of the EU Global Strategy. These include:

- conflict prevention,

- initial stabilisation,

- humanitarian interventions and rescue tasks, 
- crisis management,

- peace-keeping.

In accordance with the concept, the Battle Groups are a specific form of rapid response elements. They are one of the ways of securing the necessary capabilities to be conducted by EU in crisis management operations. In this context, the Battle Groups can be defined as military units, usually composed of 1500 personnel each and form an integral part of the European Union's military rapid reaction capacity to respond to emerging crises and conflicts around the world. These forces are formed from elements of all types of troops of the battalion size, with the Combat Support (CS) and Combat Service Support (CSS) elements (Kawałowski, 2007, p. 56). Their exact composition depends on the specificities of the mission and the participating countries. EU Battle Groups are based on the principle of multi-nationality. This may also include non-EU countries, as is the case in the Nordic Battle Group where six EU Member States are joined by Norway which is not a member of the EU (European Union External Action...).

The Headline Goal 2010 assumes, that the EU should decide to join the operation within 5 days from the acceptance of the concept of crisis management and forces should proceed to the execution of a task not later than within 10 days of this decision. For the purposes of planning it is assumed that Battle Groups should be able to initially sustain missions for 30 days possibly extended to 120 days if resupplied appropriately. In principle it is assumed that groups shall not carry out long-term stabilization measures. On a rotational basis, two Battle Groups are always on standby for a period of 6 months. Decision about their use shall be made unanimously by Council of the EU (in addition, such decision shall be approved in accordance with the national procedures for sending troops) (Stańczyk, 2009, p.39).

The size, composition and number of required EU BG may be defined in more detail after analyzing possible use of the Group and after determining the level of ambition for the crisis management operation, which requires a rapid response. In the Headline Goal 2010, the Member States agreed that they must be capable of rapid and strong response in the context of full spectrum of tasks, contained in article 43 of the Treaty of 
Lisbon the EU and the European Security Strategy. The article 42 paragraph 1 says that the common security and defence policy shall be an integral part of the common foreign and security policy. It shall provide the Union with an operational capacity drawing on civil and military assets. The Union may use them on missions outside the Union for peacekeeping, conflict prevention and strengthening international security in accordance with the principles of the United Nations Charter. The performance of these tasks shall be undertaken using capabilities provided by the Member States.

The basis for the generation process of the Battle Groups are the initiative of the Member States, which offer and provide forces capable to be quickly formed along with CS and CSS measures in standby of 5 to 10 days. The EU Military Committee contracts out coordination process to EU Military Staff to ensure the constant availability of the required number of Battle Groups. Member States are responsible for the provision of the necessary preparation and training of declared forces to comply with requirements. Planning and preparation, national and multinational training, as well as combat readiness of Battle Groups for example, European Union Battle Group of Visegrad Countries (V4 EU BG) lasted 30 months and included three phases:

- Phase I: Planning and preparation - 12 months,

- Phase II: Training - 12 months (national training - 6 months, multinational training - 6 months),

- Phase III: Combat readiness.

The certification of prepared elements is required after each stage of training. The certification of individual elements is responded by the State responsible for the preparation of element. However, for the certification of whole Battle Groups is responded by forming State with the participation of the representative of other countries that make up the Group additionally. The certification process is supervised by representatives of European Union Military Staff (EUMS). In order to properly prepare the forces to Battle Groups, specified operational requirements that should be accrued have been developed and include: 1) availability, 2) versatility, 3) self-sufficiency, 4) ability to moved, 5) readiness, 6) communication, 7) ability to survive, 8) medical protection, 9) interoperability. 
The basic requirement posed before Battle Groups is to provide the ability to be moved and the deployment of these forces. Member States which declare forces should provide adequate means of strategic transport, designed for the Group. Appropriate logistic support of Battle Groups is an essential component of crisis management operations. One should expect that depending on the mission and operational activities, scope of the support from host nation support (HNS) will be variable or not at all.

Currently there are two types of Battle Groups: heavy and light. The first kind is a unit composed of multiple modules, including subunits of mechanized troops, armor, aviation support and maritime components. This type of Group has approximately 3600 troops, while the type of light form is usually created by motorized subunits having to 2000 soldiers.

\section{POLISH PARTICIPATION IN THE CREATION OF THE EUROPEAN UNION BATTLE GROUPS}

Poland is very actively involved in the development of military capabilities and task Headline Goal 2010 after affiliation to the European Union. Poland was among the countries that have adopted the duty to command a multinational group as a framework. In the 2006, during a meeting of Defence Ministers an agreement on the establishment of the EU BG was signed. Based on the agreement German-Latvian-Lithuanian-Polish-Slovak EU BG was created. The Group was called "The Central Group" (Ciupiński, 2014, p.115) and Poland served as framework. The Group was formed on the basis of 17 Mechanized Brigade in Międzyrzecz and involvement was approximately: Poland 50\%, Germany 30\%, Slovakia 10\%, Lithuania 5\% and Latvia 5\%. Operation Headquarter for these forces was located in Potsdam. The Group has been certified in the course of Exercise "Common Challenge 09" in November 2009. Full operational capacity of the Central Battle Group achieved in the first half of 2010 and from January 2010 took over 6 months on duty. At that time there were no conflicts or crises that would require military intervention of the European Union.

Another contribution to the development of the Common Security and Defence Policy European Union was Polish contribution to create the next 
BG. In order to intensify cooperation between the three countries of the Weimar Triangle, and giving it practical dimension, in a meeting of Defence Ministers of Weimar Triangle States in Wieliczka in July 2006, it was agreed to create common BG in 2013. Despite the initial declarations of France concerning the function of the framework States, finally it has been decided that this function will be served by Poland. According to the declaration of the contribution countries, the Weimar Battle Group included: Poland - 2133 troops, Germany - 551 troops, France - 384 troops. Overall, the BG consisted of 3068 soldiers. Poland as a framework State issued Force Headquarters operational level (FHQ) and battalion from the $17^{\text {th }}$ Mechanized Brigade. Germany was responsible for logistic support and France was the state leading a medical security.

In January 2007, the Chief of Staffs of Poland, Czech Republic, Slovakia and Hungary performed an initiative creating extra-regional BG, in which Poland also played a leading role. In October 2009, during the meeting of Defence Ministers of the Visegrad Group, it was decided to form a common EU BG. The process of preparing to form national contingent and creating the conditions for the training components of BG ended in December 2014. The next phase of preparation was training of the components, this part was divided into stages. The first stage was a national training, including individual training of troops and FHQ staff, preparation of subunits to perform tasks at the platoon, company and battalion level and finally integrated training. The second stage was the international training, including synchronizing whole FHQ staff and integrating training subunits. After one year of training the Group was certified in the course of the international exercise "Common Challenge 15". After achieving full operational readiness, BG was on duty from 01.01.2016 to 30.06.2016. BG was an international unit composed of subunits and elements of Visegrad Group countries as well as Ukraine. Overall, the group consisted of 3909 troops, of which Poland assigned approximately 50\%, Czech Republic 19\%, Slovakia 12\%, Hungary 16\% and Ukraine 3\% (the detailed structure of V4BG is illustrated in Figure 1). At the same time, together with the Visegrad Group, Balkan BG led by Greece was on duty. Originally referred to as HELBROC, it consisted of military units from Greece, Bulgaria, Romania and Cyprus. Additionally in 2011, the Balkan 
BG was joined by Ukraine. Taking into account the equipment and number of soldiers, this group can be classified as "light" BG. By comparing the structure and capacity of these groups one can see the difference, "heavy" group was - V4 BG and "light" was HELBROC BG.

The EU BG is created as multinational. This group can be created by one country or international coalition of Member States of the EU and the partner States. However, one country is designated as responsible. The necessary criteria for the creation of the group are interoperability and military effectiveness. The creation of Battle Groups involved $24 \mathrm{EU}$ countries: Austria, Belgium, Bulgaria, Cyprus, the Czech Republic, Estonia, Finland, France, Greece, Spain, the Netherlands, Lithuania, Luxembourg, Latvia, Germany, Poland, Portugal, Romania, Slovakia, Slovenia, Sweden, Hungary, United Kingdom, Italy and from outside community: Norway, Turkey, Macedonia and Ukraine.

The main problem for Battle Groups remains unchanged for a long time and concerns their use. The main factor blocking their use is lack of political will. BG is ready for tasks and the Member States creating the group bear the financial costs, but there is no decision when and how to use them. Another important aspect are the deficiencies in the full cast of the timesheet roster - in accordance with the concept of Battle Groups two groups should be on standby. The recent crises, for example in Libya, Mali and the Central African Republic were indications for use of EU Battle Groups. However, the complex nature of potential military operations, when the sides of conflict are not always identified and impartiality is virtually impossible, made the Council of the European Union not to take decision about the use of Battle Groups in such areas. In addition, an important aspect for many countries, blocking the use of Battle Groups, are financial issues i.e. a particularly high cost and transport by air. Further $\mathrm{EU}$ action should be aimed at increasing the frequency of forming Battle Groups by framework countries. An alternative solution is also a voluntary extension of standby period to 12 months by each Member State. The idea to create Battle Groups, outside of European Union's ability to quickly respond to emerging crises in various parts of world, had also ensured to increase the military capacity. Therefore, this organization had become a major player on the international stage, with a significant impact on the 
development of the situation in Europe and neighbouring countries. The creation of new military capabilities was also the stimulus for the development of the Member States national armed forces. The modernization process of the armed forces of countries involved in the implementation of the "Headline Goal 2010" was carried out in accordance with the financial possibilities. However, when trying to assess the validity of the creation of the EU Battle Groups, the answer is not so clear. According to many experts, Battle Groups are too small and have limited capabilities for strategic air transport, which limits their ability to take action in a significant distance from Europe. Moreover, taking into account their capabilities, these forces are not able to participate in classic peace-keeping operations. With regard to the peaceful operation, Battle Groups should be used to prevent humanitarian disasters or to provide security during the elections, as well as organizing the non-combatant evacuation operation. Another problem in functioning of Battle Groups is duplication of their tasks with the forces declared to NATO, for example NATO Response Forces (NRF) or the simultaneous assignation of the same forces and means on duty for the EU Battle Groups and NRF.

\section{CONCLUSION}

According to the concept, the European Union Battle Groups are planned to participate in humanitarian and preventive and stabilization missions, including forcing and maintaining peace. If a decision is made to intervene, the Group must be ready to act within a maximum of ten days from that moment. If necessary, soldiers can be moved to the area of the crisis at a distance of up to six thousand kilometers from Brussels. EU Battle Group should be able to act independently for 30 days, with the possibility of extending this period to 120 days. EU Battle Groups are to perform tasks resulting from the Common Security and Defense Policy (CSDP), i.e. Petersburg tasks [humanitarian and rescue operations, peacekeeping operations, combat tasks related to crisis management operations, including peacemaking operations], and also tasks resulting from the European security strategy (integrated disarmament operations, support 


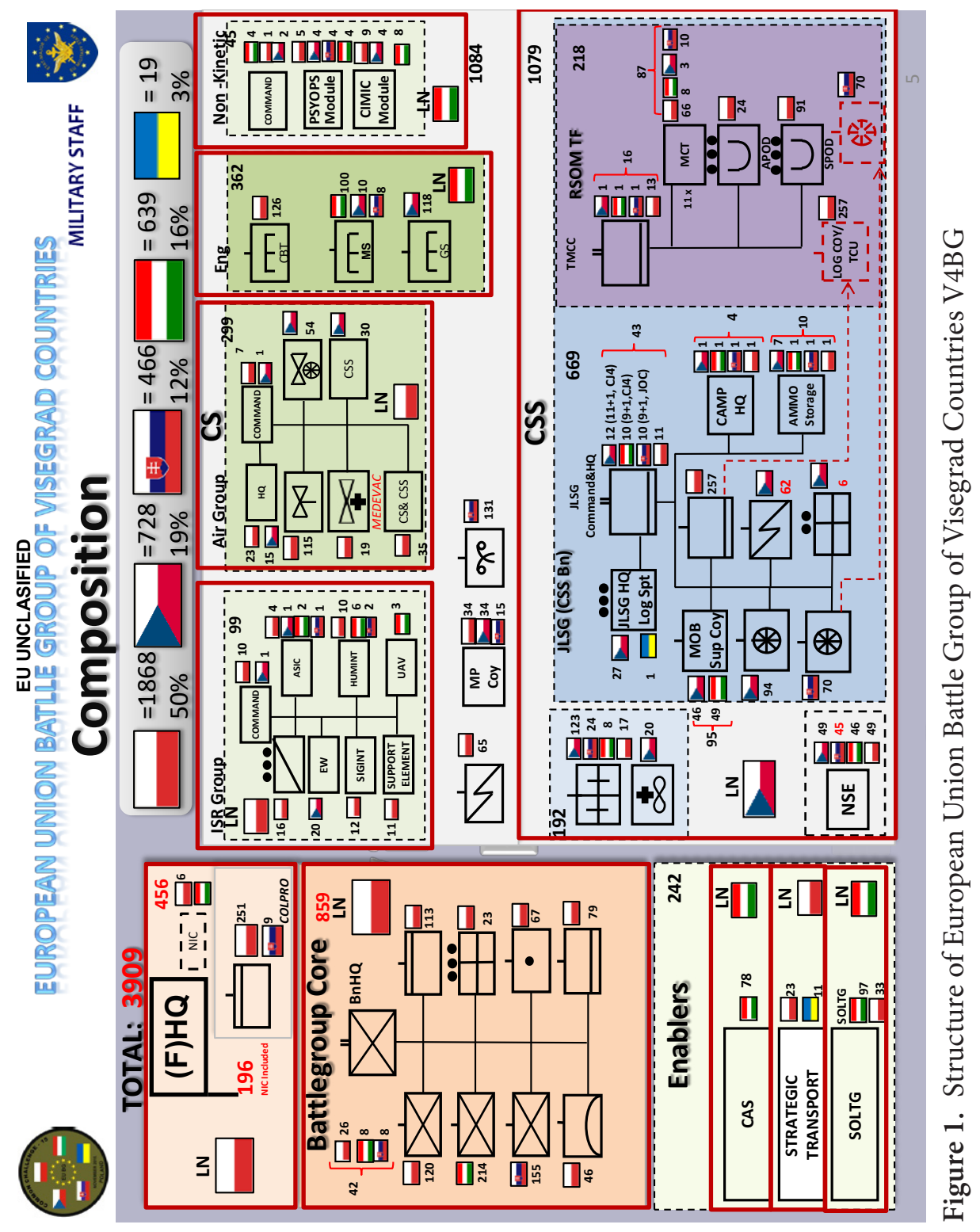


operations of third countries in the fight against terrorism, operations to support the reform of the security sector and, more broadly, the mission of building state institutions). EU Battle Groups are primarily intended to enable the EU to engage independently in missions and operations around the world and contribute to increasing its operational capabilities. This should lead to the strengthening of the Union's position in the international arena as a result of the strengthening of hard power resources.

\section{BIBLIOGRAPHY:}

Ciupiński, A. (2001). Rola Francji w kształtowaniu europejskiej autonomii strategicznej, Warszawa: Wydawnictwo Akademii Obrony Narodowej.

Ciupiński, A. (2014). Zdolności wojskowe Unii Europejskiej. Perspektywy grup bojowych. Rocznik integracji europejskiej, 8.

Czapliński, W., Ostrihansky, R., Wyrozumski, A. (eds.). (1996). Prawo Wspólnot Europejskich. Dokumenty, Warszawa: Agencja Scholar.

Cziomer, E. (ed.), (2001). Raport o bezpieczeństwie 2000, Kraków: Instytut Studiów Strategicznych.

European Union External Action, Downloaded from: https://eeas.europa.eu/headquarters/headQuarters-homepage/33557/eu-battlegroups_en

Fijałkowska, B., Żukrowski, A. (eds.) (2002). Unifikacja i różnicowanie się współczesnej Europy, Warszawa: Dom Wydawniczy ELIPSA.

Gaddis, J.L. (2008). Strategie powstrzymywania, Warszawa: Książka i Wiedza.

Hamon, D., Keller, I.S. (1997). Fondements et etapes de la construction europeenne. Paris: Presses Universitaires de France - PUF.

Helsinki European Council, Presidency conclusion, 10-11 December 1999; Anex IV: Presidency Reports to the Helsinki European Council on Strengthening Common European Policy on security and Defence and on Non-Military Crisis Management of the European Union, Downloaded from: www. Europa. eu. int/ council/ off conclu/ dec/ 99-en. Htm.

Kawałowski, M. (2007). Zaangażowanie Polski w Grupach Bojowych Unii Europejskiej. Zeszyty Naukowe AON, 3.

Lindley-French J., Headline Goal 2010 and The Concept of The EU Battle Groups: An Assessment of The Build-Up of a European Defence Capability, Paris, 9 December 2005, Downloaded from: http://www.cicerofoundation.org/pdf/lecture_lindleyfrench_ dec05.pdf. 
Stańczyk, J. (2009). Grupy Bojowe jako element polityki reagowania kryzysowego Unii Europejskie. Studia Europejskie/Centrum Europejskie Uniwersytetu Warszawskiego, 4. Zięba, R. (2000). Europejska Tożsamość Bezpieczeństwa i brony. Koncepcja - struktura - funkcjonowanie, Warszawa: Wydawnictwo Naukowe SCHOLAR.

Zięba, R. (2005). Europejska Polityka Bezpieczeństwa i Obrony, Warszawa: Wydawnictwo Sejmowe. 